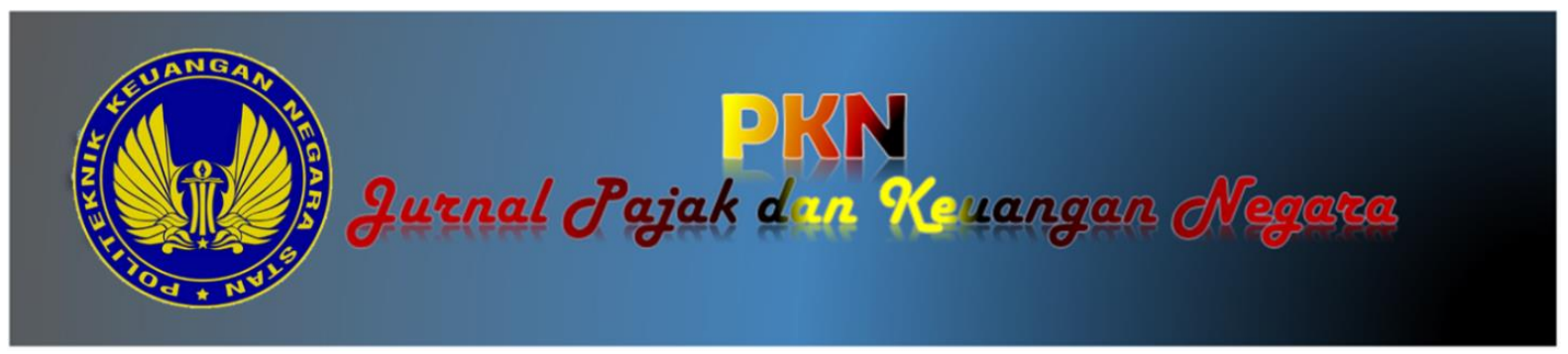

\title{
PENGARUH PENGECILAN MODAL, TRANSAKSI HUBUNGAN ISTIMEWA, DAN PROFITABILITAS TERHADAP TAX AVOIDANCE
}

\author{
Johan Budhi Santoso, Dadang Sadeli, dan Surtikanti \\ Universitas Pancasila
}

Alamat Korespondensi: caraka107@gmail.com

\section{INFORMASI ARTIKEL \\ Diterima Pertama \\ [26 06 2021] \\ Dinyatakan Diterima \\ [28 07 2021]}

\section{KATA KUNCI:}

Pengecilan Modal, Transaksi Hubungan Istimewa, Profitabilitas, Penghindaran Pajak

\section{KLASIFIKASI JEL:}

H26

\section{ABSTRACT}

For some people, taxes are a burden that can reduce their income, moreover not get a direct reward when paying taxes, this is the cause of the practice of tax avoidance. This study aims to test and provide empirical evidence of the influence between the thin capitalization, special relationship transactions and profitability of tax avoidance. This research was conducted at manufacturing company listed on BEI period of observation year 2012-2016. Sampling method used is purposive sampling method with samples of 54 companies during the observation period 5 years in a row so that the total sample 270. The results of this study indicate that the transaction variable related to the affiliated debt proxy has a negative effect on tax avoidance practices which are proxied by the company's effective tax rate (ETR). The results of this study also show that the profitability variable with the Return on Assets (ROA) proxy has a positive effect on tax avoidance practices. The results of this study also show that the profitability variable with the Return on Assets (ROA) proxy has a positive effect on tax avoidance practices. Based on the results of this study, tax avoidance practices are not affected by capital reduction and related transactions with affiliate receivable proxies.

\section{ABSTRAK}

Bagi sebagian masyarakat, pajak adalah beban yang dapat mengurangi penghasilan mereka, terlebih lagi tidak didapatkan imbalan secara langsung ketika membayar pajak, hal inilah yang menjadi penyebab terjadinya praktik penghindaran pajak. Penelitian ini bertujuan untuk menguji dan memberikan bukti empiris pengaruh antara pengecilan modal, transaksi hubungan istimewa dan profitabilitas terhadap penghindaran pajak. Penelitian ini dilakukan di perusahaan manufaktur yang terdaftar di BEI periode tahun pengamatan 2012-2016. Metode penentuan sampel yang digunakan adalah metode purposive sampling dengan sampel sebanyak 54 perusahaan selama periode pengamatan 5 tahun berturut-turut sehingga total sampel 270 . Hasil penelitian ini menunjukkan bahwa variabel transaksi hubungan istimewa dengan proksi utang afiliasi berpengaruh negatif terhadap praktik penghindaran pajak yang diproksikan dengan tarif pajak efektif perusahaan (ETR). Hasil penelitian ini juga menunjukkan bahwa variabel profitabilitas dengan proksi Return on Assets (ROA) berpengaruh positif terhadap praktik penghindaran pajak. Berdasarkan hasil penelitian ini, praktik penghindaran tidak dipengaruhi oleh pengecilan modal dan transaksi hubungan istimewa dengan proksi piutang afiliasi. 


\section{PENDAHULUAN}

Bagi sebagian besar negara, pajak menjadi sumber utama pendapatan negara, tidak terkecuali di Indonesia. Dana yang berasal dari pendapatan negara digunakan untuk membiayai pembangunan dan pemerintahan, untuk itu pentingnya peranan masyarakat sebagai wajib pajak diperlukan dalam pembangunan negara. Salah satu peran masyarakat yaitu memenuhi kewajiban perpajakannya dengan baik dan benar. Direktorat Jenderal Pajak (DJP), sebagai pengelola administrasi perpajakan di Indonesia, selalu berusaha untuk meningkatkan penerimaan pajak guna mensejahterakan rakyat.

Suminarsasi dan Supriyadi (2011) menyatakan bahwa pajak yang dibayarkan rakyat belum sepenuhnya dirasakan untuk kepentingan umum. Hal tersebut dapat menyebabkan masyarakat merasa enggan dalam membayarkan kewajiban pajaknya. Salah satu indikasi adanya keengganan masyarakat untuk membayarkan kewajiban pajaknya dapat dilihat melalui selalu tidak tercapainya target penerimaan pajak. Berbagai macam realitas mengenai tidak tercapainya target penerimaan pajak, di antaranya masih ada masyarakat yang tidak melaporkan semua penghasilannya, karena bagi masyarakat pajak adalah beban yang dapat mengurangi penghasilan mereka, terlebih lagi tidak mendapatkan imbalan langsung ketika membayar pajak. Hal inilah yang menyebabkan banyak dari masyarakat bahkan perusahaan yang melakukan penghindaran pajak (tax avoidance) (Maharani dan Suardana, 2014).

Fenomena penghindaran pajak (tax avoidance) yang mencuat pada tahun 2016 silam adalah mengenai Panama Papers yang dilaporkan oleh International Consortium of Investigative Journalists (ICIJ). Lebih dari 214.000 informasi perusahaan cangkang (shell company) yang terdaftar di dua puluh satu negara suaka atau surga pajak (tax havens countries) diungkap.

Laporan ICIJ menjelaskan bagaimana para pejabat, politisi, dan kaum super kaya menyembunyikan kekayaannya melalui pendirian perusahaan cangkang di negara-negara surga pajak. Panama Papers sendiri menunjukkan betapa besarnya potensi penghindaran pajak yang terjadi, termasuk di Indonesia (Deddy, 2016). Berdasarkan bocoran dokumen tersebut ada sekitar 800 nama pebisnis dan politikus Indonesia yang masuk dalam daftar klien Mossack Fonseca, sebuah firma hukum yang sangat berpengaruh di Panama (Tempo.co, 2016). Hal tersebut menunjukkan adanya indikasi bahwa di Indonesia terjadi penghindaran pajak secara besar-besaran.

Kasus penggelapan pajak yang di lakukan oleh PT Asia Agri menjadi salah satu fenomena penghindaran pajak (tax avoidance) di Indonesia. PT Asian Agri merupakan sebuah perusahaan swasta di Indonesia yang memproduksi minyak sawit mentah (crude palm oil). Kasus dari perusahaan tersebut yaitu penggelapan

pajak. Perusahaan diketahui telah berbohong dalam pengisian Surat Pemberitahuan Pajak Asian Agri sehingga didakwa melakukan Penggelapan pajak perusahaan sebesar Rp 1,25 triliun pada periode 2002-2005. (Tempo.co,2007).

Selain PT Asian Agri, kasus praktik penghindaran pajak (tax avoidance) juga menimpa kepada PT Toyota Motor Manufacturing Indonesia dengan melakukan skandal transfer pricing. Petugas pajak menemukan sejumlah kejanggalan saat pemeriksaan SPT Toyota pada tahun 2005. Laba kotor Toyota anjlok lebih dari 30 persen pada 2004, dari Rp1,5 triliun (2003) menjadi Rp950 miliar. Selain itu, dari tahun 2003 sampai 2004, rasio gross margin, atau perimbangan antara laba kotor dan tingkat penjualan, juga penurunan dari sebelumnya 14,59 persen menjadi hanya 6,58 persen. Hasil pemeriksaan pajak menunjukan bahwa Toyota diduga menambah biaya lewat pembayaran royalty serat memainkan harga transaksi dengan pihak terafiliasi (Tempo.co, 2014).

Indonesia menduduki peringkat ketujuh terbesar sebagai negara asal dana illicit (aliran dana haram) di seluruh dunia berdasarkan fenomena penghindaran pajak (tax avoidance) pada laporan GFI (Global Financial Integrity) (Aditya \& Perkasa, 2015). Dari laporan tersebut menyatakan bahwa aliran dana haram dari aktivitas penghindaran pajak beserta ilegal lainnya mencapai US\$6,6 triliun sepanjang satu dekade terakhir, sehingga estimasi kehilangan uang yang dialami oleh Indonesia setiap tahunnya bisa mencapai Rp240 triliun atau setara kurang lebih empat persen produk domestik bruto. Beberapa uraian fenomena yang dipaparkan di atas merupakan bukti bahwa praktik penghindaran pajak (tax avoidance) selama beberapa tahun ini menjadi isu yang penting untuk mendapatkan perhatian lebih.

Di dalam bidang perpajakan dikenal istilah pengecilan modal (thin capitalization) dan transfer pricing. Pengecilan modal (thin capitalization) merupakan pembentukan struktur permodalan suatu perusahaan dengan proporsi hutang jauh lebih besar dari modal saham. Hal ini bisa terjadi karena aturan pajak memperbolehkan 
mengurangkan biaya bunga sebagai unsur pengurang (deductible expense) dalam menghitung penghasilan kena pajak, sedangkan dividen bukan merupakan unsur pengurang (nondeductible espense) (OECD Model, 2012).

Selain pengecilan modal (thin capitalization) dan transfer pricing dalam lingkup transaksi hubungan istimewa, ada faktor lainnya yang diduga mempengaruhi tindakan penghindaran pajak, yaitu profitabilitas. Profitabilitas suatu perusahaan menggambarkan kemampuan suatu perusahaan dalam menghasilkan laba selama periode tertentu pada tingkat penjualan, asset dan modal saham tertentu.

Penelitian mengenai praktik penghindaran pajak (tax avoidance) telah banyak dijadikan sebagai objek penelitian dan faktor-faktor yang mempengaruhinya telah banyak diuji oleh peneliti sebelumnya. Namun penelitian yang telah dilakukan menunjukkan simpulan yang beragam dengan variabel independen yang beragam pula. Faktor-faktor yang diduga mempengaruhi praktik penghindaran pajak (tax avoidance) berdasarkan penelitian sebelumnya. Hasil penelitian Waluyo, dkk (2010), I Gusti Ayu dan Ketut Alit (2014), Agusti (2014), serta Ayu dan Ery (2016) menjukkan adanya pengaruh yang signifikan antara profitabilitas dan tax avoidance. Sebaliknya, penelitian Cahyono, dkk. (2016), Ismi dan Linda (2016), dan Ambarukmi dan Diana (2017) menunjukkan tidak adanya pengaruh signifikan antara profitabilitas dan tax avoidance.

Khomsatun (2015) menguji adanya pengaruh yang signifikan antara thin capitalization (pengecilan modal) dan tax avoidance. Hasil penelitian sebaliknya mengungkapkan bahwa tidak ada pengaruh yang signifikan antara thin capitalization (pengecilan modal) dan tax avoidance yang dilakukan oleh Cahyono, dkk. (2016) dan Ismi dan Linda (2016).

Belum banyak penelitian dengan menggunakan variabel independen transaksi hubungan istimewa terhadap tax avoidance. Tercatat Handayani dan Arfan (2014) serta Oktavia, dkk (2012) yang melakukan penelitian tersebut. Hasil penelitiannya menunjukkan adanya pengaruh positif adanya praktik transaksi hubungan istimewa terhadap penghindaran pajak (tax avoidance).

Berdasarkan fenomena yang ada, maka penulis terdorong untuk melakukan pengujian kembali untuk mengetahui faktor apa saja yang mempengaruhi penghindaran pajak (tax avoidance), dengan melakukan pengembangan penelitian-penelitian terdahulu.

\section{KERANGKA TEORI DAN PENGEMBANGAN HIPOTESIS}

\subsection{Grand Theory: Agency Theory}

Alasan penggunaan Agency Theory (teori agensi) adalah karena teori ini dapat menjelaskan alasan suatu perusahaan melakukan praktik penghindaran pajak (tax avoidance). Teori Agensi mencoba untuk menjalin hubungan yang formal antara para pemilik (principal) dan agen atau pihak-pihak yang berkepentingan dalam proses penyusunan anggaran (budget). Teori ini menekankan pada perancangan pengukuran prestasi dan imbalan yang diberikan agar para manajer berperilaku positif atau menguntungkan perusahaan secara keseluruhan (Eko Raharjo, 2007). Pada seluruh hubungan keagenan, terdapat kemungkinan terjadinya benturan kepentingan antara para pemilik dan agennya. Benturan kepentingan tersebut disebut dengan permasalahan keagenan (Ross, 2015).

Sebagai agen, manajer bertanggung jawab secara moral untuk mengoptimalkan keuntungan para pemilik, namun demikian manajer juga menginginkan untuk selalu memperoleh kompensasi sesuai dengan kontrak. Dari hal tersebut terdapat dua kepentingan yang berbeda di dalam perusahaan di mana masing-masing pihak berusaha untuk mencapai atau mempertahankan tingkat kemakmuran yang dikehendaki (Azis, 2014).

Salah satu cara untuk meningkatkan kemakmuran perusahaan adalah dengan adanya upaya meminimalisasikan pajak yang biasanya dilakukan dengan teknik perencanaan pajak (tax planning). Tax planning merupakan cara Wajib Pajak untuk mendapat penghematan pajak (tax saving) melalui prosedur penghindaran pajak (tax avoidance) secara sistematis sesuai ketentuan Undang-Undang Perpajakan (Hoffman, 1961). Bagi manajemen, dengan meminimalisasikan pajak maka laba yang dihasilkan akan lebih tinggi sehingga meningkatkan bonus yang akan mereka dapatkan. Hal ini dapat merugikan pihak prinsipal karena mereka tidak terlibat langsung dalam pengelolaan perusahaan dan menginginkan pihak manajamen dapat mengelola perusahaan secara optimal tanpa melakukan penyimpangan.

\subsection{Midle Theory: Theory of Planned Behavior}

Theory of Planned Behavior dapat membantu menjelaskan kecenderungan penghindaran pajak perusahaan yang direncanakan karena Theory of Planned Behavior dapat mengkaji perilaku yang lebih spesifik, yaitu perilaku untuk tidak patuh terhadap ketentuan perpajakan (Hidayat,2010). 
Berdasarkan model Theory of Planned Behavior oleh Ajzen (1991) dalam Hidayat (2010), dapat dijelaskan bahwa perilaku individu untuk tidak patuh terhadap ketentuan perpajakan dipengaruhi oleh niat (intention) untuk berperilaku tidak patuh.

Theory of Planned Behavior merupakan teori yang sesuai untuk menjelaskan perilaku wajib pajak dalam memenuhi kewajiban perpajakannya. Sebelum individu melakukan sesuatu, individu tersebut akan memiliki keyakinan mengenai hasil yang akan diperoleh dari perilakunya tersebut. Kemudian yang bersangkutan akan memutuskan bahwa akan melakukannya atau tidak melakukannya. Hal tersebut berkaitan dengan kesadaran wajib pajak. Wajib pajak yang sadar pajak, akan memiliki keyakinan mengenai pentingnya membayar pajak untuk membantu menyelenggarakan pembangunan negara (behavioral beliefs) (Mustikasari, 2007).

\subsection{Pengecilan Modal (Thin Capitalization)}

Menurut Siahaan (2010) Praktik pengecilan modal (thin capitalization) merupakan praktik yang secara berlebihan mendanai cabang atau anak perusahaan dengan pinjaman berbunga dari mereka yang memiliki hubungan istimewa. Menurut Khomsatun dan Martani (2015) perusahaan multinasional, pengecilan modal (thin capitalization) dilakukan dengan memberikan pinjaman perusahaan cabang dibandingkan dengan harus memberikan modal tambahan, apalagi jika perusahaan cabang berada dalam lingkungan yang memiliki tingkat pajak tinggi.

2.3.1. Indikator Pengecilan Modal (Thin

\section{Capitalization}

Menurut Fadhil Ismi dan Linda (2016): pengecilan modal (thin capitalization) adalah batasan rasio total utang terhadap modal.

Menurut Pasal 18 ayat (1) UU PPh menyebutkan bahwa Menteri Keuangan memiliki kewenangan untuk mengeluarkan keputusan tentang besarnya perbandingan antara utang dan modal perusahaan yang dapat dibenarkan untuk keperluan penghitungan pajak, yaitu tingkat perbandingan tertentu yang wajar mengenai besarnya debt to equity ratio.

Berdasarkan penjelasan di atas, maka indikator yang digunakan dalam penelitian pengaruh pengecilan modal (thin capitalization) terhadap praktik pengindaran pajak (tax avoidance) adalah debt to equity ratio (DER).

$$
\text { Debt to equity ratio }=\frac{\text { total liability }}{\text { total equity }}
$$

Sumber: Fadhil Ismi dan Linda (2016)

\subsection{Transfer Pricing dalam Transaksi Afiliasi (Hubungan Istimewa)}

Menurut Lingga (2012), transfer pricing adalah transaksi barang dan jasa antara beberapa divisi pada suatu kelompok usaha dengan harga yang tidak wajar, bisa menaikkan (mark up) atau menurunkan harga (mark down) dan kebanyakan dilakukan oleh perusahaan global (multinational enterprise) dan yang dimaksud dengan perusahaan multinasional adalah perusahaan yang beroperasi di lebih dari satu negara di bawah pengendalian satu pihak tertentu. Transfer pricing juga sering dikaitkan dengan suatu rekayasa harga secara sistematis yang ditujukan untuk mengurangi laba yang nantinya akan mengurangi jumlah pajak atau bea dari suatu negara (Mangoting, 2000).

2.4.1. Indikator Transaksi Hubungan Istimewa

Menurut Oktavia dkk (2012): Piutang hubungan istimewa dan hutang hubungan istimewa dalam laporan keuangan timbul karena adanya transaksi antara pihak-pihak yang mempunyai hubungan istimewa yang dapat menjadi indikator dalam penelitian pengaruh transaksi hubungan istimewa terhadap praktik penghindaran pajak (tax avoidance).

Transaksi hubungan istimewa

$$
\begin{aligned}
& =\frac{\text { piutang hubungan istimewa }}{\text { total aset }} \\
& =\frac{\text { utang hubungan istimewa }}{\text { total aset }}
\end{aligned}
$$

Sumber: Oktavia dkk (2012)

\subsection{Profitabilitas}

Ambarukmi dan Dian (2017) menyatakan bahwa Profitabilitas adalah kemampuan perusahaan memperoleh laba dalam hubungannya dengan penjualan dan efisiensi perusahaan, total asset maupun modal sendiri.

Menurut I Gusti Ayu dan Ketut Ali (2014) profitabilitas merupakan salah satu pengukuran bagi kinerja suatu perusahaan. Profitabilitas suatu perusahaan menggambarkan kemampuan suatu perusahaan dalam menghasilkan laba selama periode tertentu pada tingkat penjualan, asset dan modal saham tertentu.

\subsubsection{Indikator Profitabilitas}

Salah satu alat untuk mengukur profitabilitas adalah dengan menggunakan Return on Asset (ROA). ROA menunjukkan efektivitas perusahaan dalam mengelola asset baik modal sendiri maupun dari modal pinjaman, investor akan melihat seberapa efektif perusahaan dalam mengelola asset. Semakin tinggi ROA maka akan memberikan 
efek terhadap penjualan saham, artinya laba perusahaan akan meningkat (Agusti, 2014). Perusahaan yang memperoleh laba diasumsikan tidak melakukan penghindaran pajak (tax avoidance) karena mampu mengatur pendapatan dan pembayaran pajaknya (I Gusti Ayu dan Ketut Ali, 2014).

Berdasarkan penjelasan di atas, maka indikator yang digunakan dalam penelitian pengaruh Profitabilitas terhadap praktik penghindaran pajak (Tax Avoidance) adalah Return on Assets (ROA).

$$
\text { Return on assets }=\frac{\text { laba sebelum pajak }}{\text { total aset }} \times 100 \%
$$

Sumber: I Gusti Ayu dan Ketut Ali (2014)

\subsection{Penghindaran Pajak (Tax Avoidance)}

Menurut Handayani (2015) Penghindaran pajak (tax avoidance) adalah strategi dan teknik penghindaran pajak yang dilakukan secara legal karena tidak bertentangan dengan ketentuan perpajakan. Teguh dan Yessi (2010) ukuran mengukur kepatuhan kewajiban perpajakan biasanya diukur dan dibandingkan dengan besar kecilnya penghematan pajak (tax saving), penghindaran pajak (tax avoidance), dan penggelapan pajak (tax evasion) dengan beberapa cara antara lain melalui pengecualianpengecualian, pengurangan-pengurangan, insentif pajak, penghasilan yang bukan objek pajak, penangguhan pengenaan pajak, pajak ditanggung negara sampai kepada kerja sama dengan aparat perpajakan dengan suap-menyuap dan pemalsuan.

\subsubsection{Indikator Penghindaran Pajak (Tax}

\section{Avoidance)}

Menurut Khomsatun dan Martani (2015): perbedaan maksud dan definisi penghindaran pajak (tax avoidance) berdampak pada perbedaan proksi untuk mengukur penghindaran pajak (tax avoidance)., kebanyakan peneliti menggunakan tarif pajak efektif atau effective tax rate (ETR).

Menurut Handayani dan Arfan (2014): Tarif pajak efektif (ETR) adalah besarnya beban pajak penghasilan yang terutang dibagi dengan penghasilan sebelum pajak. Beban pajak penghasilan terutang yang dimaksud adalah jumlah pajak penghasilan terutang perusahaan pada satu periode. Jumlah pajak penghasilan terutang atas penghasilan kena pajak pada satu periode disebut juga sebagai beban pajak kini.

Tax avoidance $=\frac{\text { beban pajak kini }}{\text { penghasilan kena pajak }} \times 100 \%$

Sumber: Handayani dan Arfan (2014)

\subsection{Hipotesis}

2.7.1. Pengaruh Pengecilan Modal (Thin Capitalization) terhadap Penghindaran Pajak (Tax Avoidance)

Ada dua alternatif bagi perusahaan untuk mendapatkan pendanaan, yaitu dengan menerbitkan saham dan menerbitkan obligasi atau peminjaman lainnya dengan menggunakan bunga. Dalam perpajakan, dividen yang dibagikan kepada pemegang saham tidak dapat dijadikan pengurang pajak penghasilan, sedangkan bunga dapat dijadikan sebagai pengurang pajak penghasilan. Maka banyak perusahaan lebih senang memperoleh dana berasal dari utang karena dapat mengurangi biaya pajak yang dibebankan. Begitu pula dengan perusahaan multinasional. Adanya praktik pengecilan modal (thin capitalization) terjadi karena banyak perusahaan multinasional yang secara berlebihan mendanai cabang atau anak perusahaan dengan pinjaman berbunga dari mereka yang memiliki hubungan istimewa (Siahaan, 2010). Hal ini dilakukan untuk mengurangi beban pajak, apalagi jika perusahaan cabang berada dalam lingkungan yang memiliki tingkat pajak tinggi.

Dari hasil penelitian Khomsatun (2015) menunjukkan bahwa pengecilan modal (thin capitalization) berpengaruh secara signifikan terhadap penghindaran pajak (tax avoidance). Bunga merupakan unsur pengurang dalam perhitungan penghasilan kena pajak. Semakin besar pinjaman yang diberikan maka semakin besar biaya bunga yang dapat dikurangkan dari penghasilan kena pajak.

2.7.2. Pengaruh Transaksi Hubungan Istimewa terhadap Pengindaran Pajak (Tax Avoidance)

Transaksi hubungan istimewa telah menjadi perhatian khusus dalam ketentuan peraturan perpajakan, apalagi jika transaksi tersebut diduga digunakan untuk tujuan penghindaran pajak dengan cara melaporkan penghasilan kurang dari yang seharusnya atau pembebanan biaya di luar batas kewajaran (Oktavia, 2012). Transfer pricing merupakan salah satu contoh transaksi hubungan istimewa yang didefinisikan sebagai transaksi barang dan jasa antara beberapa divisi pada suatu kelompok usaha dengan harga yang tidak wajar. Menurut Mangoting (2000) transfer pricing juga sering dikaitkan dengan suatu rekayasa harga secara sistematis yang ditujukan untuk mengurangi laba yang nantinya akan mengurangi jumlah pajak atau bea dari suatu negara.

Dari hasil penelitian Oktavia dkk (2012), Handayani dan Arfan (2014) serta Suprihatin (2016) menyatakan bahwa transaksi hubungan 
istimewa berpengaruh secara signifikan terhadap penghindaran pajak (tax avoidance). Transfer pricing dalam hubungan istimewa merupakan rekayasa harga secara sistematis yang memiliki tujuan untuk mengurangi laba yang nantinya akan mengurangi pajak yang dibebankan.

\subsubsection{Pengaruh Profitabilitas terhadap} Penghindaran Pajak (Tax Avoidance)

Profitabilitas terdiri dari beberapa rasio, salah satunya adala return on assets. Return on Assets (ROA) adalah suatu indikator yang mencerminkan performa keuangan perusahaan, semakin tingginya nilai ROA yang mampu diraih oleh perusahaan maka performa keuangan perusahaan tersebut dapat dikategorikan baik. ROA dilihat dari laba bersih perusahaan dan pengenaan Pajak Penghasilan (PPh) untuk Wajib Pajak Badan. Pengukuran kinerja dengan ROA menunjukkan kemampuan dari modal yang diinvestasikan dalam keseluruhan aktiva untuk menghasilkan laba. ROA adalah rasio keuntungan bersih pajak yang juga berarti suatu ukuran untuk menilai seberapa besar tingkat pengembalian dari aset yang dimiliki perusahaan. ROA yang negatif disebabkan laba perusahaan dalam kondisi negatif (rugi) pula. Hal ini menunjukkan kemampuan dari modal yang diinvestasikan secara keseluruhan aktiva belum mampu menghasilkan laba. Perusahaan yang memperoleh laba diasumsikan tidak melakukan penghindaran pajak (tax avoidance) karena mampu mengatur pendapatan dan pembayaran pajaknya (I Gusti Ayu dan Ketut Alit, 2014).

Hasil penelitian Teguh dan Yessi (2010), I Gusti Ayu dan Ketut Alit (2014), Agusti (2014), dan Ida Ayu dan Putu Ery (2016) mengatakan bahwa profitabilitas berpengaruh secara signifikan terhadap penghindaran pajak (tax avoidance).

Dari pengembangan hipotesis tersebut, maka dapat dirumuskan hipotesis sebagai berikut.

$\mathrm{H}_{1}$ : Pengecilan modal (thin capitalization) berpengaruh terhadap penghindaran pajak (tax avoidance).

$\mathrm{H}_{2}$ : Transaksi hubungan istimewa berpengaruh terhadap penghindaran pajak (tax avoidance).

$\mathrm{H}_{3}$ : Profitabilitas berpengaruh terhadap penghindaran pajak (tax avoidance).

$\mathrm{H}_{4}$ : Pengecilan modal (thin capitalization), transaksi hubungan istimewa dan profitabilitas secara bersama-sama berpengaruh terhadap penghindaran pajak (tax avoidance).

Berikut ini merupakan kerangka penelitian dari pengembangan hipotesis.

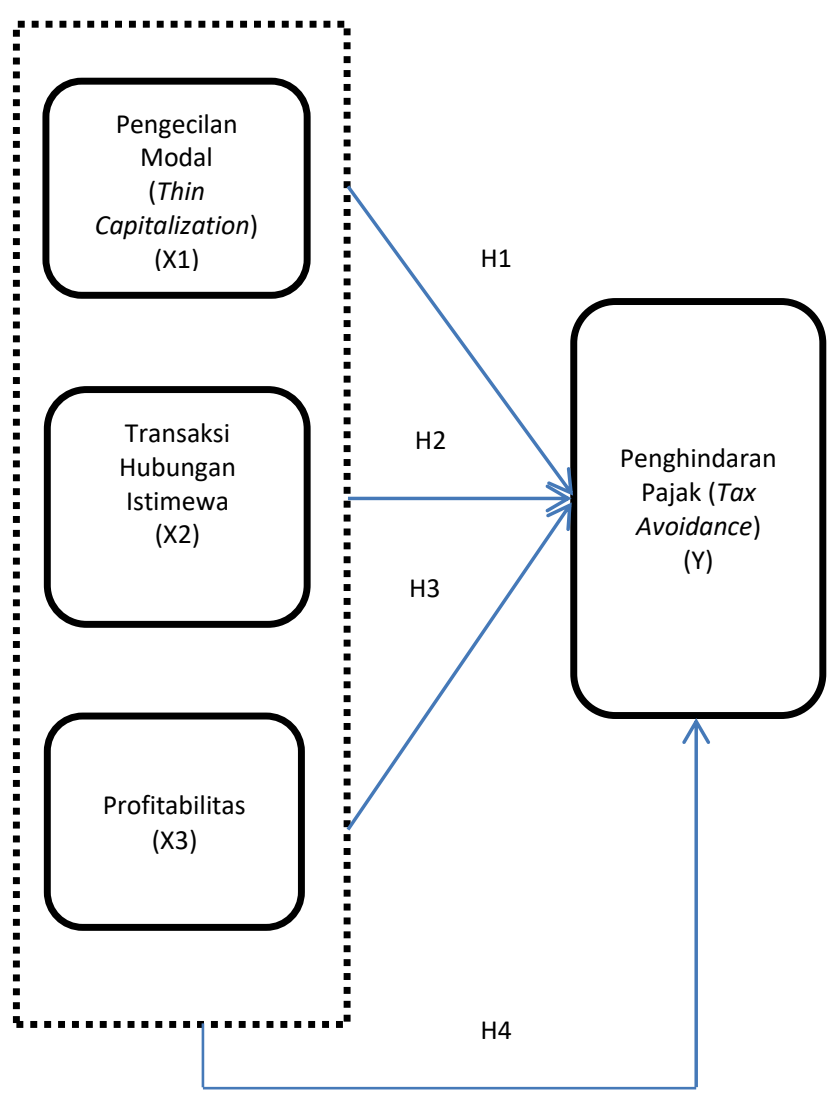

Gambar 1. Kerangka Penelitian

\section{METODE PENELITIAN}

Pada penelitian ini, jenis penelitian yang digunakan adalah verifikatif, yaitu penelitian yang memiliki tujuan untuk menguji kembali ilmu pengetahuan yang sudah ada. Penelitian ini merupakan pengembangan dari pengujian penelitian sebelumya yang terjadi gap hasil sehingga dapat menguji kebenaran teori-teori akuntansi dan perpajakan. Metode Penelitian digunakan dalam penelitian ini adalah explanatory survey dengan tujuan untuk menguji hipotesis. Penelitian ini ingin menguji seberapa besar pengaruh pengecilan modal (thin capitalization), transaksi afiliasi, dan profitabilitas terhadap penghindaran pajak (tax avoidance). Teknik penelitian yang digunakan oleh penulis statistik inferensial yaitu teknik penelitian yang digunakan untuk mengolah data kuantitatif dengan tujuan untuk menguji kebenaran suatu hipotesis. Penulis memilih individual sebagai unit analisis pada penelitian ini, yang mana sumber datanya merupakan respons individu emiten manufaktur yang tercatat di Bursa Efek Indonesia.

Populasi dalam penelitian ini adalah 640 Laporan Keuangan dari 128 perusahaan manufaktur yang terdaftar pada tahun 2012-2016 
di Bursa Efek Indonesia (BEI). Teknik pengambilan sampel yang digunakan dalam penelitian ini adalah nonprobability sampling, yaitu teknik pengambilan sampel yang tidak memberikan peluang yang sama bagi setiap unsur atau anggota populasi untuk dipilih menjadi sampel (Sugiono, 2009). Dalam penelitian ini perusahaan yang menjadi sampel dipilih berdasarkan purposive sampling (kriteria yang dikehendaki). Kriteria sampel dalam penelitian ini adalah sebagai berikut: 1) perusahaan manufaktur yang terdaftar berturutturut di Bursa Efek Indonesia (BEI) dari tahun 2012 - 2016; 2) perusahaan manufaktur yang selama tahun penelitian 2012-2016 secara konsisten memperoleh laba; 3) Perusahaan manufaktur yang secara lengkap mempublikasikan laporan keuangan selama tahun penelitian 2012-2016; dan 4) tersedia data Laporan Tahunan di website perusahaan, bursa efek, atau situs performance profile.

Berdasarkan metode ini, diperoleh 270 Laporan Keuangan sampel pengamatan yang memenuhi kriteria seperti yang disebutkan dengan rincian sebagai berikut:

Tabel 1. Daftar Rincian Sampel

\begin{tabular}{|c|c|}
\hline Keterangan & $\begin{array}{c}\text { Jumlah } \\
\text { Sampel } \\
\text { Pengamatan }\end{array}$ \\
\hline $\begin{array}{l}\text { Perusahaan manufaktur yang } \\
\text { terdaftar berturut-turt di Bursa } \\
\text { Efek Indonesia (BEI) dari tahun } \\
2012-2016 \text {. }\end{array}$ & 128 \\
\hline $\begin{array}{l}\text { Perusahaan manufaktur yang } \\
\text { selama tahun penelitian } 2012-2016 \\
\text { secara tidak konsisten memperoleh } \\
\text { laba }\end{array}$ & 74 \\
\hline $\begin{array}{l}\text { Jumlah Perusahaan Manufaktur } \\
\text { yang menjadi sampel }\end{array}$ & 54 \\
\hline Jumlah Sampel Penelitian (54 x 5) & 270 \\
\hline
\end{tabular}

Sumber : Data Diolah

Variabel dependen ialah varibel yang dapat dipengaruhi oleh variabel lain, dalam penelitian ini variabel dependennya adalah penghindaran pajak (tax avoidance) (Y) yang diproksikan dengan effective tax rates (ETR). Variabel independen merupakan variabel yang mempengaruhi atau yang menjadi sebab perubahannya atau timbulnya variabel dependen / terikat. Variabel independen dalam penelitian ini adalah Pengecilan Modal (Thin Capitalization) yang diproksikan dengan DER (Debt Equity Ratio), Transaksi Hubungan Istimewa diukur dengan menggunakan piutang hubungan istimewa dan hutang hubungan istimewa yang terdapat di dalam laporan keuangan auditan, dan Profitabilitas dengan menggunakan Return on Asset (ROA).

Metode analisis yang dipakai untuk menguji hipotesis yang telah dikemukakan adalah dengan menggunakan teknik analisis regresi berganda (multiple regression), yaitu metode yang dipergunakan untuk masalah penelitian yang melibatkan satu variabel tak bebas $Y$ yang datanya berbentuk skala rasio yang memengaruhi atau terkait dengan lebih dari satu variabel bebas $X$ yang skala pengukurannya rasio.

1. Uji Pool Model

Uji pool model dilakukan untuk menetukan jenis model yang digunakan apakah panel model atau commol model. Uji ini merupakan deteksi awal apakah data panel yang akan diolah harus diestimasi menggunakan panel model atau common model yang diuji menggunakan Chow test.

2. Uji Spesifikasi Model

Uji spesifikasi model dilakukan untuk menetukan jenis model yang digunakan dalam estimasi apakah random effect atau fixed effect. Uji ini diperlukan karena data yang akan diolah merupakan data panel, yaitu gabungan data cross section dengan data time series. Uji spesifikasi model dilakukan menggunakan Hausman test.

3. Pengujian Asumsi Klasik

Pengujian asumsi klasik adalah persyaratan statistik yang harus dipenuhi pada analisis linear berganda yang berbasis ordinary least square (OLS). Uji asumsi klasik yang digunakan adalah uji normalitas.

4. Pengujian Hipotesis

Uji $t$ digunakan untuk menguji signifikansi pengaruh antara faktor fundamental (DER, TPR, TPD, ROA) terhadap pajak (tax avoidance). Uji F digunakan untuk menguji signifikansi pengaruh antara faktor-faktor fundamental (DER, TPR, TPD, ROA) terhadap tax avoidance secara simultan.

\section{HASIL PENELITIAN}

4.1. Analisis Verifkatif

Pada bagian ini akan diuji pengaruh pengecilan modal (thin capitalization), transaksi hubungan istimewa dan profibilitas terhadap penghindaran pajak (tax avoidance) pada perusahaan manufaktur di Bursa Efek Indonesia menggunakan analisis regresi berganda. Pengujian akan dilakukan melalui tahapan sebagai berikut.

4.1.1. Uji Pool Model

Uji ini merupakan deteksi awal apakah data panel yang akan diolah harus diestimasi menggunakan panel model atau common model 
yang diuji menggunakan Chow test dan hasilnya sebagai berikut:

Tabel 2. Hasil Chow Test Untuk Menguji Common Model atau Panel Model

\begin{tabular}{|l|l|l|}
\hline Fhitung & probability & Kesimpulan \\
\hline 6,24 & $<0,0001$ & panel model \\
\hline
\end{tabular}

Sumber: Lampiran Output Eviews Model Akhir

Hasil pengujian pool model menunjukkan bahwa panel model merupakan pilihan yang tepat digunakan dalam estimasi model regresi. Hal ini ditunjukkan oleh hasil Chow test yang signifikan pada level $5 \%$ (nilai probability $<0,05$ ). Karena kesimpulan dari Chow test adalah panel model maka dilanjutkan uji spesifikasi model.

\subsubsection{Uji spesifikasi}

Model dilakukan untuk menetukan jenis model yang digunakan dalam estimasi apakah random effect atau fixed effect. Uji ini diperlukan karena data yang akan diolah merupakan data panel, yaitu gabungan data cross section dengan data time series. Uji spesifikasi model dilakukan menggunakan Hausman test dan hasilnya sebagai berikut:

Tabel 3. Hasil Uji Hausman Untuk Menentukan Model Fixed atau Model Random

\begin{tabular}{|l|l|l|l|}
\hline$\chi^{2}$ hitung & $\chi^{2}$ tabel & probability & Kesimpulan \\
\hline 9,97 & 9,488 & 0,041 & fixed effect \\
\hline
\end{tabular}

Sumber: Lampiran Output Eviews Model Akhir

Hasil Hausman test menunjukkan bahwa fixed effect merupakan pilihan yang tepat untuk estimasi model untuk menguji pengaruh pengecilan modal (thin capitalization), transaksi hubungan istimewa dan profibilitas terhadap penghindaran pajak (tax avoidance), hal ini ditunjukkan oleh hasil uji Hausman yang signifikan pada level $5 \%$ (nilai probability $<0,05$ ).

\subsection{Pengujian Asumsi Klasik}

Pada penelitian ini keempat asumsi yang disebutkan tersebut diuji karena variabel independen yang digunakan pada penelitian ini lebih dari satu (berganda) dan data yang digunakan mengandung unsur time series.

Tabel 4. Hasil Pengujian Asumsi Normalitas

\begin{tabular}{|l|c|c|l|}
\hline Statistik & Jarque Berra & Probablity & Keterangan \\
\hline Residual & 995,08 & $<0,0001$ & Tidak Normal \\
\hline
\end{tabular}

Sumber: Lampiran Output Eviews Model Awal

Pada tabel 4 dapat dilihat nilai probability yang diperoleh dari uji Jarque-Bera untuk nilai residual masih lebih kecil dari 0,05, maka dapat disimpulkan bahwa data berdistribusi tidak normal. Model regresi tidak berdistribusi normal disebabkan karena terdapat beberapa data outlier (pencilan). Untuk menanggulangi masalah tersebut, data outlier harus dikeluarkan dari model regresi. Dari data residual terdapat data outlier pada 17 perusahaan, setelah ke-17 perusahaan tersebut dikeluarkan dari model regresi, diperoleh hasil uji normalitas yang baru sebagai berikut.

Tabel 5. Hasil Pengujian Asumsi Normalitas Model

$$
\text { Revisi }
$$

\begin{tabular}{|c|c|c|c|}
\hline Statistik & $\begin{array}{c}\text { Jarque } \\
\text { Berra }\end{array}$ & Probablity & Keterangan \\
\hline Residual & 0,67 & 0,967 & Normal \\
\hline
\end{tabular}

Sumber: Lampiran Output Eviews Model Akhir

Setelah ke-17 perusahaan yang memiliki data outlier (pencilan) dikeluarkan dari model model regresi, dapat dilihat nilai probability yang diperoleh dari uji Jarque-Bera lebih besar dari 0,05 sehingga dapat disimpulkan bahwa model regressi sudah berdistribusi normal.

\subsection{Pengaruh Pengecilan Modal (Thin Capitalization) Terhadap Penghindaran Pajak (Tax Avoidance) \\ Ringkasan hasil pengujian yang digunakan} untuk menguji pengaruh pengecilan modal (thin capitalization) terhadap penghindaran pajak (tax avoidance) dapat dilihat pada tabel 6 berikut.

Tabel 6. Hasil uji pengaruh pengecilan modal (thin capitalization) terhadap penghindaran pajak (tax avoidance)

\begin{tabular}{|c|c|c|c|c|}
\hline $\begin{array}{c}\text { Koefisien } \\
\text { regresi }\end{array}$ & thitung $_{\text {Probability }}$ & $\begin{array}{c}\mathbf{t}_{\text {tabel }} \\
\text { (df=143) }\end{array}$ & Ho \\
\hline$-0,007$ & $-1,555$ & 0,122 & 1,977 & diterima \\
\hline
\end{tabular}

Hasil pengujian seperti disajikan pada tabel 8 dapa dilihat nilai thitung variabel pengecilan modal (thin capitalization) sebesar -1,555 dengan nilai probabilitas sebesar 0,122. Karena nilai thitung (1,555) berada di antara $-1,977$ dan 1,977 maka pada tingkat kekeliruan $5 \%$ diputuskan untuk menerima Ho sehingga $\mathrm{Ha}$ ditolak. Dengan demikian dapat disimpulkan bahwa pengecilan modal (thin capitalization) tidak berpengaruh terhadap penghindaran pajak (tax avoidance).

4.4. Pengaruh Transaksi Hubungan Istimewa Terhadap Penghindaran Pajak (Tax Avoidance)

Ringkasan hasil pengujian yang digunakan untuk menguji pengaruh transaksi hubungan istimewa terhadap penghindaran pajak (tax avoidance) dapat dilihat pada tabel 7 berikut.

Tabel 7. Hasil uji pengaruh transaksi hubungan istimewa piutang afiliasi terhadap penghindaran pajak (tax avoidance)

\begin{tabular}{|c|c|c|c|c|}
\hline $\begin{array}{c}\text { Koefisien } \\
\text { regresi }\end{array}$ & thitung $_{\text {probability }}$ & $\begin{array}{c}\mathbf{t}_{\text {tabel }} \\
\text { (df=143) }\end{array}$ & Ho \\
\hline 0,081 & 1,352 & 0,178 & 1,977 & diterima \\
\hline
\end{tabular}


Berdasarkan hasil pengujian seperti disajikan pada tabel 7 diperoleh nilai thitung variabel transaksi hubungan istimewa piutang sebesar 1,352 dengan nilai probabilitas sebesar 0,178 . Karena nilai thitung $(1,352)$ berada di antara $-1,977$ dan 1,977 maka pada tingkat kekeliruan $5 \%$ diputuskan untuk menerima $\mathrm{Ho}$ sehingga $\mathrm{Ha}$ ditolak. Dengan demikian dapat disimpulkan bahwa transaksi hubungan istimewa piutang afiliasi tidak berpengaruh terhadap penghindaran pajak (tax avoidance).

\subsection{Pengaruh Profitabilitas Terhadap Penghindaran Pajak (Tax Avoidance)}

Ringkasan hasil pengujian yang digunakan untuk menguji pengaruh profitabilitas terhadap penghindaran pajak (tax avoidance) dapat dilihat pada tabel 8 berikut.

Tabel 8. Hasil uji pengaruh profitabilitas terhadap penghindaran pajak (tax avoidance)

\begin{tabular}{|l|l|l|l|l|}
\hline $\begin{array}{l}\text { Koefisien } \\
\text { regresi }\end{array}$ & thitung $_{\text {hrobability }}$ & $\begin{array}{l}\mathbf{t}_{\text {tabel }} \\
\text { (df=143) }\end{array}$ & Ho \\
\hline 0,054 & 2,082 & 0,039 & 1,977 & Ditolak \\
\hline
\end{tabular}

Pada tabel 8 dapat dilihat nilai thitung variabel profitabilitas sebesar 2,082 dengan nilai probabilitas sebesar 0,039. Karena nilai thitung $(2,082)$ lebih besar dari $t_{\text {tabel }}(1,977)$ maka pada tingkat kekeliruan 5\% diputuskan untuk menolak Ho sehingga Ha diterima. Dengan demikian dapat disimpulkan bahwa profitabilitas berpengaruh terhadap penghindaran pajak (tax avoidance) pada perusahaan manufaktur di Bursa Efek Indonesia.

4.6. Pengaruh Pengecilan Modal (Thin Capitalization), Transaksi Hubungan istimewa dan Profitabilitas terhadap Pengindaran Pajak (Tax Avoidance)

Ringkasan hasil pengujian yang digunakan untuk menguji pengaruh pengecilan modal (thin capitalization), transaksi hubungan istimewa, dan profitabilitas terhadap penghindaran pajak (tax avoidance) dapat dilihat pada tabel 9 berikut.

Tabel 9. Hasil uji pengaruh simultan terhadap Penghindaran pajak (tax avoidance)

\begin{tabular}{|c|c|c|c|c|}
\hline $\begin{array}{l}\text { Koefisien } \\
\text { determina } \\
\text { si }\end{array}$ & Fhitung & $\begin{array}{c}\text { probabili } \\
\text { ty }\end{array}$ & $\begin{array}{c}F_{\text {tabel }} \\
(41 \& 143)\end{array}$ & Ho \\
\hline 0,8105 & 20,679 & $<0,001$ & 1,474 & ditolal \\
\hline
\end{tabular}

Pada tabel 9 dapat dilihat nilai $F_{\text {statistic }}$ dari hasil pengolahan data sebesar 20,679 dengan nilai probabilitas mendekati nol. Nilai ini menjadi statistik uji yang akan dibandingkan dengan nilai $\mathrm{F}$ dari tabel, karena $F_{\text {statistic }}(20,679)$ lebih besar dari Ftabel $(1,474)$ maka pada tingkat kekeliruan 5\% $(\alpha=0.05)$ diputuskan untuk menolak Ho sehingga $\mathrm{Ha}$ diterima. Sehingga disimpulkan bahwa pengecilan modal (thin capitalization), transaksi hubungan istimewa dan profibilitas secara simultan berpengaruh terhadap penghindaran pajak (tax avoidance) pada perusahaan manufaktur di Bursa Efek Indonesia

\subsection{Pembahasan}

4.7.1. Pengaruh Pengecilan Modal (Thin Capitalization) Terhadap Penghindaran Pajak (Tax Avoidance)

Hasil uji hipotesis menunjukan hipotesis ditolak karena thitung $\leq t_{\text {tabel, }}$ dan nilai probabilitas mencapai 0.122 atau $12.2 \%$ yang berada di atas tingkat probabilitas yang diinginkan yaitu sebesar 0,05 atau $5 \%$ agar diterimanya hipotesis penelitian, hal tersebut menunjukan pengecilan modal (thin capitalization) tidak berpengaruh signifikan terhadap penghindaran pajak (tax avoidance) pada perusahaan manufaktur yang terdaftar di BEl. Penelitian ini menunjukkan bahwa tidak terjadi pengaruh apapun antara thin capitalization dan tax avoidance. Hal ini sejalan dengan hasil penelitian yang dilakukan oleh Ismi dan Linda (2016) pada perusahaan JII (Jakarta Islami Index).

Penelitian ini menjelaskan bahwa pengecilan modal (thin capitalization) dengan cara memperbesar hutang dibandingkan dengan modal (DER) tidak mempengaruhi adanya praktik tax avoidance pada perusahaan manufaktur yang terdaftar di BEI. Hal ini dapat dijelaskan bahwa perusahaan manufaktur yang terdaftar di BEI merupakan perusahaan terbuka, dimana seluruh informasi laporan keuangan dapat diakses oleh semua pihak yang berkepentingan dan mendapat pengawasan melekat dari instansi terkait (Bapepam, DJP dsb), sehingga upaya untuk melakukan tax avoidance melalui thin capitalization cenderung untuk tidak dilakukan. Selama periode 2012 s.d. 2016 mayoritas hutang yang dimiliki oleh perusahaan manufaktur yang terdaftar di BEI adalah hutang yang berasal dari pinjaman bank baik jangka pendek maupun jangka panjang dan hutang usaha serta sebagian kecil dari utang hubungan istimewa.

4.7.2. Pengaruh Transaksi Hubungan Istimewa Terhadap Penghindaran Pajak (Tax Avoidance)

Apabila transaksi hubungan istimewa diukur dengan menggunakan piutang afiliasi, maka tidak berpengaruh terhadap penghindaran pajak (tax avoidance) karena $t_{\text {hitung }} \leq t_{\text {tabel, }}$ dan nilai probabilitas mencapai 0.1783 atau $17.8 \%$ yang berada di atas tingkat probabilitas yang diinginkan yaitu sebesar 0,05 atau 5\% agar diterimanya hipotesis penelitian. $\mathrm{Hal}$ ini menunjukan bahwa transaksi hubungan istimewa 
piutang afiliasi tidak mempengaruhi suatu perusahaan melakukan penghindaran pajak. Walaupun tidak berpengaruh terhadap penghindaran pajak, namun piutang afiliasi dapat memberikan dampak positif terhadap perusahaan karena terkait dengan pemberian pinjaman kepada pihak afiliasi dimana perusahaan memperoleh pendapatan bunga atau terkait dengan transaksi penjualan kepada pihak afiliasi di dalam negeri dimana perusahaan memperoleh keuntungan. Hal ini ditunjukan dengan nilai koefisien regresi mununjukan angka positif sebesar 0.081 .

Apabila transaksi hubungan istimewa diukur dengan menggunakan utang afiliasi, maka berpengaruh terhadap penghindaran pajak (tax avoidance) karena thitung $\geq t_{\text {tabel }}$ dan nilai probabilitasnya berada di angka 0.044 atau $4.4 \%$ dan berada dibawah tingkat probabilitas yang diinginkan yaitu sebesar 0,05 atau 5\% agar diterimanya hipotesis penelitian. Pengaruh yang ditunjukan adalah negatif signifikan dengan nilai koefisen regresi sebesar negatif 0.139 , hal ini menunjukkan bahwa semakin tinggi nilai utang afiliasi, maka semakin rendah tarif pajak efektif perusahaan (ETR) yang menunjukan adanya upaya penghindaran pajak (tax avoidance) yang dilakukan perusahaan.

Penelitian ini menunjukkan bahwa terjadi pengaruh antara transaksi hubungan istimewa utang afiliasi dengan penghindaran pajak (tax avoidance). Hal ini sejalan dengan hasil penelitian yang dilakukan oleh Oktavia dkk (2012) pada perusahaan yang listing di BEI tahun 2008 2010. Penelitian ini menjelaskan bahwa transkasi hubungan istimewa utang afiliasi mempengaruhi adanya praktik penghindaran pajak (tax avoidance) pada perusahaan manufaktur yang terdaftar di BEI. Hal ini menjawab fenomena bahwa pemberian utang dari pihak yang mempunyai hubungan istimewa mempunyai tujuan terselubung untuk memperkecil jumlah pajak yang dibayar dengan cara membentuk biaya bunga yang diperkenankan secara aturan perpajakan sebagai pengurang penghasilan bruto. Lain halnya apabila utang hubungan istimewa diwujudkan dalam bentuk tambahan modal, maka akan terbentuk pembayaran deviden yang secara aturan perpajakan bukan merupakan pengurang penghasilan bruto.

\subsubsection{Pengaruh Profitabilitas Terhadap} Penghindaran Pajak (Tax Avoidance)

Hasil uji hipotesis menunjukan hipotesis diterima karena $t_{\text {hitung }} \geq t_{\text {tabel, }}$ dan nilai probabilitas mencapai 0.0391 atau $3.9 \%$ yang berada di bawah tingkat probabilitas yang diinginkan yaitu sebesar 0,05 atau 5\% agar diterimanya hipotesis penelitian, hal tersebut menunjukan profitabilitas berpengaruh terhadap penghindaran pajak (tax avoidance) pada perusahaan manufaktur yang terdaftar di BEI. Pengaruh yang ditunjukan adalah positif signifikan, hal ini menunjukkan bahwa semakin tinggi nilai profitabilitas, maka semakin tinggi tarif pajak efektif perusahaan (ETR) yang dapat menunjukan tidak adanya upaya penghindaran pajak (tax avoidance) yang dilakukan perusahaan.

Penelitian ini menunjukkan bahwa terjadi pengaruh antara profitabilitas dengan penghindaran pajak (tax avoidance). Hal ini sejalan dengan hasil penelitian yang dilakukan oleh Teguh dan Yessi (2010), I Gusti Ayu dan Ketut Alit (2014), Agusti (2014), dan Ida Ayu dan Putu Ery (2016). Penelitian ini menjelaskan bahwa profitabilitas mempengaruhi adanya praktik penghindaran pajak (tax avoidance) pada perusahaan manufaktur yang terdaftar di BEI. Hal ini menjawab fenomena bahwa profitabilitas yang diukur dengan Return on Assets (ROA) mencerminkan performa keuangan perusahaan yang sebanding dengan laba yang diperoleh, semakin tinggi nilai ROA, maka akan semakin bagus performa perusahaan tersebut karena laba yang dihasilkan tinggi. Perusahaan yang memperoleh laba diasumsikan tidak melakukan penghindaran pajak (tax avoidance) karena mampu mengatur pendapatan dan pembayaran pajaknya.

4.7.4. Pengaruh Pengecilan Modal (Thin Capitalization), Transaksi Hubungan istimewa dan Profitabilitas terhadap Pengindaran Pajak (Tax Avoidance)

Hasil uji hipotesis menunjukan hipotesis diterima karena $t_{\text {hitung }} \geq t_{\text {tabel, }}$ dan nilai probabilitas mencapai 0.001 atau $0.1 \%$ yang berada di bawah tingkat probabilitas yang diinginkan yaitu sebesar 0,05 atau $5 \%$ agar diterimanya hipotesis penelitian, hal tersebut menunjukan pengecilan modal (thin capitalization), transaksi hubungan istimewa dan profitabilitas secara simultan berpengaruh terhadap penghindaran pajak (tax avoidance) pada perusahaan manufaktur yang terdaftar di BEI.

Berdasarkan hasil pengolahan nilai adjusted R-Square sebesar 0,8105 atau 81,05 persen. Artinya pengecilan modal (thin capitalization), transaksi hubungan istimewa dan profibilitas secara simultan memberikan kontribusi atau pengaruh sebesar $81,05 \%$ terhadap penghindaran pajak (tax avoidance) pada perusahaan manufaktur di Bursa Efek Indonesia. Sisanya dipengaruhi oleh faktor-faktor lain yang tidak diteliti sebesar 18,95\% yaitu dapat meliputi 
proporsi dewan komisaris, kualitas audit, komite audit, risiko perusahaan, pertumbuhan penjualan dan kepemilikan institusional.

\section{KESIMPULAN DAN SARAN}

\subsection{Kesimpulan}

Dari pengujian yang telah dilakukan, dapat diambil kesimpulan bahwa terdapat hasil uji hipotesis yang diterima dan ditolak dengan perincian sebagai berikut:

1. Pengecilan modal (thin capitalization) tidak berpengaruh signifikan terhadap penghindaran pajak (tax avoidance) pada perusahaan yang terdaftar di Bursa Efek Indonesia. Hal ini disebabkan karena perusahaan manufaktur yang terdaftar di BEI merupakan perusahaan terbuka, dimana seluruh informasi laporan keuangan dapat diakses oleh semua pihak yang berkepentingan dan mendapat pengawasan melekat dari instansi terkait (Bapepam, DJP dsb), sehingga upaya untuk melakukan penghindaran pajak (tax avoidance) melalui pengecilan modal (thin capitalization) cenderung untuk tidak dilakukan.

2. Transaksi hubungan istimewa piutang afiliasi tidak berpengaruh signifikan terhadap penghindaran pajak (tax avoidance) pada perusahaan yang terdaftar di Bursa Efek Indonesia. Hal ini disebabkan karena transaksi hubungan istimewa piutang afiliasi dapat memberikan dampak positif bagi perusahaan dalam memperoleh tambahan laba yang berasal dari pendapatan bunga dan/atau keuntungan dari penjualan kepada pihak afiliasi di dalam negeri.

3. Transaksi hubungan istimewa utang afiliasi berpengaruh signifikan terhadap penghindaran pajak (tax avoidance). Pengaruh yang ditunjukan adalah negatif signifikan, hal ini berarti semakin besar nilai transaksi hubungan istimewa berupa hutang afiliasi, maka tarif pajak efektif (ETR) perusahaan semakin menurun yang dapat menunjukan terjadinya penghindaran pajak. Pemberian utang dari pihak yang mempunyai hubungan istimewa disinyalir mempunyai tujuan terselubung untuk memperkecil jumlah pajak yang dibayar dengan cara membentuk biaya bunga yang diperkenankan secara aturan perpajakan sebagai pengurang penghasilan bruto.

4. Profitabilitas berpengaruh signifikan terhadap pengindaran pajak (tax avoidance). Pengaruh yang ditunjukan adalah positif signifikan, hal ini berarti semakin besar nilai profitabilitas, maka tarif pajak efektif (ETR) perusahaan semakin tinggi. Sehingga diasumsikan perusahaan yang memiliki profitabilitas yang tinggi tidak melakukan penghindaran pajak (tax avoidance) karena mampu mengatur pendapatan dan pembayaran pajaknya dengan baik.

5.2. Saran

Penghitungan penghindaran pajak (tax avoidance) menggunakan ETR tidak mampu menangkap perbedaan laba fiskal, sehingga disarankan untuk peneliti selanjutnya menggunakan proksi perhitungan tax avoidance selain menggunakan pendekatan ETR yaitu salah satunya dengan menggunakan Book Tax Difference (BTD).

\section{IMPLIKASI DAN KETERBATASAN}

Ada pun implikasi penelitian ini sebagai berikut.

1. Direktorat Jenderal Pajak

Diharapkan hasil penelitian ini dapat menjadi bahan masukan untuk menjadi pertimbangan bagi Direktorat Jenderal Pajak selaku otoritas pajak Pemerintah Republik Indonesia dalam mendeteksi upaya penghindaran pajak (tax avoidance) yang dilakukan oleh Wajib Pajak Badan khususnya perusahaan manufaktur yang terdaftar di Bursa Efek Indonesia dengan cara melakukan analisis laporan keuangan secara lebih mendalam terhadap Wajib Pajak yang melakukan transaksi hubungan istimewa.

2. Emiten

Diharapkan hasil penelitian ini dapat menjadi tambahan bahan referensi mengenai jenis transaksi yang diindikasikan sebagai praktik penghindaran pajak (tax avoidance) yang dapat memberikan efek buruk bagi perusahaan, sehingga cenderung untuk tidak dilakukan.

3. Investor

Diharapkan hasil penelitian ini dapat menjadi bahan pertimbangan bagi investor dalam menanamkan modalnya dengan memilih emiten yang tidak melakukan praktik penghindaran pajak (tax avoidance) yaitu dengan cara membaca dan mengamati laporan keuangan emiten.

\section{DAFTAR PUSTAKA (REFERENCES)}

Ajzen Agusti. W. Y. (2014). Pengaruh Profitabilitas, Leverage, dan Corporate Governance terhadap Tax Avoidance. Jurnal Akuntansi Vol. 2 No. 3 Tahun 2014. Tersedia di http://bit.ly/2vvB012. Diakses pada 20 Mei 2017. In-text reference: Agusti (2014)

Ambarukmi. K. dan Diana. N. (2017). Pengaruh Size, Leverage, Profitability, Capital Intensity Ratio dan Activity Ratio 
Terhadap Effective Tax Rate (ETR). EJurnal IImiah Riset Akuntansi Vol. 06 No. 17 Tahun 2017. Tersedia di http://bit.ly/2w1WPjE. Diakses pada 20 Mei 2017. In-text reference: Ambarukmi dan Diana (2017)

Ayu. I dan Ery. P. (2016). Pengaruh Ukuran Perusahaan, Umur Perusahaan, Profitabilitas, Leverage, dan Pertumbuhan Penjualan terhadap Tax Avoidance. EJurnal Akuntansi Universitas Udayana Vol. 14.3. Tahun 2016. Tersedia di http://bit.ly/2vzZApB. Diakses pada 20 Mei 2017. In-text reference: Ayu dan Ery (2016)

Cahyono, dkk. (2016). Pengaruh Komite Audit, Kepemilikan Institusional, Dewan Komisaris, Ukuran Perusahaan (Size), Leverage (DER) dan Profitabilitas (ROA) terhadap Tindakan Penghindaran Pajak (Tax Avoidance) pada Perusahaan Perbankan yang Listing BEI Periode Tahun 2011 - 2013. Journal of Accounting Volume 2 No. 2 Tahun 2016. Tersedia di http://bit.ly/2vvlvjc. Diakses pada 20 Mei 2017. In-text reference: Cahyono, dkk. (2016)

Deddy S. (2015). ICIJ: Indonesia Urutan ke-95 Skandal Swiss Leaks. CNN Indonesia Edisi Jumat. 13/2/2015. Tersedia di http://bit.ly/2fDPfFg. Diakses pada 27 Mei 2017. In-text reference: (Deddy, 2016)

Handayani dkk. (2015). Pengaruh Return on Asset, Karakter Eksekutif, dan dimensi tata kelola perusahaan yang baik terhadap tax avoidance. Syariah paper accounting. ISSN 2460-0784. In-text reference: Handayani, dkk (2015)

Handayani, D dan Arfan, T. (2014). Pengaruh Transaksi Perusahaan Afiliasi terhadap Tarif Pajak Efektif. Jurnal Akuntansi Keuangan dan Bisnis Vol. 7 Tahun 2014. Tersedia di http://bit.ly/2wVCOrs. Diakses pada 20 Mei 2017. In-text reference: Handayani dan Arfan (2014)

Ismi, F. dan Linda. (2016). Pengaruh Thin Capitalization, Return On Asset, dan Corporate Governance pada Perusahaan Jakarta Islami Index (JII). Jurnal IImiah Mahasiswa Ekonomi Akuntansi (JIMEKA) Vol. 1, No. 1, (2016) Halaman 150-165. Tersedia di http://bit.ly/2wHItDA. Diakses pada 20 Mei 2017. In-text reference: Ismi dan Linda (2016)
Ita Salsalina Lingga. (2012). Aspek Perpajakan Dalam Transfer Pricing dan Problematika Praktik Penghindaran Pajak (Tax Avoidance). Jurnal Zenit, Vol. 1 No. 3 Tahun 2012, hlm: 210-221. Tersedia di http://bit.ly/2vTeJF2. Diakses pada 20 Mei 2017. E-Jurnal IImiah Riset Akuntansi Vol. 06 No. 17 Tahun 2017. Tersedia di http://bit.ly/2w1WPjE. In-text reference: Lingga (2012)

Khomsatun, S dan Martani, D. (2015). Pengaruh Thin Capitalization dan Assets Mixperusahaan Indeks Saham Syariah Indonesia (ISSI) terhadap Penghindaran Pajak. SNA XVII 2015. Tersedia di http://bit.ly/2fCITG8. Diakses pada 20 Mei 2017. In-text reference: Khomsatun (2015)

Maharani. I. G. A. C dan Suardana. K. A. (2014). Pengaruh Corporate Governance, Profitabilitas dan Karakteristik Eksekutif pada Tax Avoidance Perusahaan Manufaktur. E-Jurnal Akuntansi Universitas Udayana Vol. 9 No. 2 Tahun 2014. Tersedia di http://bit.ly/2hWDGcJ. Diakses pada 27 Mei 2017. In-text reference: (Maharani dan Suardana, 2014).

OECD. (2010). OECD Transfer Pricing Guidlines for Multinational Enterprises and Tax Administrations. In-text reference: (OECD Model, 2012).

Oktavia, dkk. (2012). Transaksi Hubungan Istimewa dan Pengaruhnya terhadap Tarif Pajak Efektif Perusahaan. Jurnal Akuntansi Vol. 12 No. 2 Tahun 2012. Tersedia di http://bit.ly/2vSNzOz. Diakses pada 20 Mei 2017. In-text reference: Oktavia, dkk (2012)

Redaksi Tempo. (2014). Lika Liku Transfer Prcing. Tersedia di http://bit.ly/2uDMrdC. Diakses pada 27 Mei 2017. In-text reference: (Tempo.co, 2016).

Richard Siahaan. (2010). Analisis Kebijakan Penangkal Praktik Thin Capitalization di Indonesia. Depok: Universitas Indonesia. Tersedia di http://bit.ly/2vB9ZRV. Diakses pada 20 Mei 2017. In-text reference: (Siahaan, 2010)

Suminarsasi. W and Supriyadi. (2011). Pengaruh Keadilan, Sistem Perpajakan, dan Diskriminasi terhadap Persepsi Wajib Pajak mengenai Etika Penggelapan Pajak (Tax Evasion). Yogyakarta: Universitas Gajah Mada. Tersedia di http://bit.ly/2w1EbbW. Diakses pada 27 
Mei 2017. In-text reference: Suminarsasi dan Supriyadi (2011)

Waluyo, dkk. (2015). Pengaruh Return on Asset, Leverage, Ukuran Perusahaan, Kompensasi Rugi Fiskal dan Kepemilikan Institusi Terhadap Penghindaran Pajak. SNA XVII 2015. Tersedia di http://bit.ly/2uDHMIH. Diakses pada 20
Mei 2017. In-text reference: Waluyo, dkk (2010).

Mangoting, Y. (2000). Aspek Perpajakan dalam Praktek Transfer Pricing. Jurnal Akuntansi \& Keuangan Vol. 2 No. 1 Tahun 2000, hlm: 69-82. Tersedia di http://bit.ly/2uATc3W. Diakses pada 20 Mei 2017. In-text reference: (Mangoting, 2000). 